\title{
Assessment of the differentiation of social and economic development of the municipal districts in the Voronezh region
}

\author{
Nataliya Yakovenko, ${ }^{1,}$, Roman Ten ${ }^{2}$, Igor $\mathrm{Komov}^{2}$, and Olga Didenko ${ }^{2}$ \\ ${ }^{1}$ Voronezh State University Forestry and Technologies named after G.F. Morozov, Timiryazev Str. 8, \\ 394087, Voronezh, Russia \\ ${ }^{2}$ Voronezh State University, Khol'zunova Str. 40, 394068, Voronezh, Russia
}

\begin{abstract}
One of the problems that have arisen in the past and have an inertial impact on the development of the Russian Federation is the problem of heterogeneity of the country's socio-economic space. The large scale of the space of Russia predetermines the predominantly macroscopic nature of the regulatory impact, the object of which is large territorial formations: economic districts, federal districts, regions of the Russian Federation. Each separate region, each municipality is a complex system with a set of unique factors: geographic location, climatic conditions, resource potential, population, etc. The article presents the author's methodology for assessing the differentiation of social and economic development of municipalities in the Voronezh region. In modern conditions, the formation of convenient and effective methods and tools for measuring sustainable social and economic development, which make it possible to give an unambiguous interpretation of the results, is of high value both from a research and management point of view. On the basis of the author's methodology, an assessment of the differentiation of the social and economic development of municipalities in the Voronezh region has been carried out. The proposed method, having individual characteristics in limiting the number of basic indicators along with the existing approaches, contributes to obtaining more objective results and allows it to be used in the development of a regional social and economic Strategy. These indicators are among the most important areas of the region's social and economic system.
\end{abstract}

\section{Introduction}

Differentiation is an inalienable property of the components of social and economic systems, traced by quantitative indicators. In the regions of Russia that are diverse in their economic and geographic conditions, peculiarities and differences in social and economic development are objectively formed: differentiation of the population in terms of income, vocational training, education, health, age, sex structure and other characteristics.

\footnotetext{
* Corresponding author: n.v.yakovenko71@gmail.com
} 
Differentiation is an indispensable condition and result of regional development. Territorial differentiation as a result, as a fact of economic and/or social reality, characterizes the regional system at a certain point in time and makes sense only in comparison with some standard, acceptable level or with another territorial system. It is known that the economic and social space cannot be completely homogeneous, and a certain level of differentiation of the social and economic space is natural and even useful. It "brings dynamism" to the development of the economy, creating a certain tension. The level of Russian regional differentiation is recognized in the literature as anomalous and is characterized by much greater differentiation in comparison with the level of acceptable unevenness for effective development [1-5]. It is important to emphasize that the assessment of territorial differentiation, firstly, is always relative, and matters only in comparison, and secondly, it can be characterized by a multitude of heterogeneous indicators. For an adequate assessment of territorial differentiation, it is also necessary to take into account the dynamics of the average indicators for the studied indicator. Thus, an increase in differentiation by any indicator against the background of an improvement in the situation on average may indicate an improvement in the situation, and vice versa. It is necessary to keep in mind the importance of choosing the measurement method and the corresponding indicator. However, the use of different indicators may in some cases lead to conflicting characteristics of differentiation. While one indicator will record an increase in differentiation, the other may show a decrease in it. In such a way, the research of unevenness of territorial development involves the use of a set of indicators that consistently fix a particular feature of differentiation.

\section{Relevance of the study}

Reducing the differentiation of the level of social and economic development of areas is one of the priority tasks for the development of regions and Russia as a whole. A significant gap in the development of municipalities complicates the implementation of a unified regional socio-economic policy and the formation of regional and national markets. In addition, there is an increasing risk of economic crises and social conflicts. In these circumstances, it is necessary to develop a methodological approach to the study of these processes, taking into account the diversity of local conditions that affect management decision-making. The proposed methodological approach aims to carry out a comprehensive analysis of the differentiation of the social and economic development of municipalities in the region. This goal setting involves a 3-step analysis, each focused on solving specific issues. Asymmetry in the social and economic development of municipalities leads to problems in the formation of investment policy, budget policy, planning the development of the social and economic sphere of the region, etc. Today in Russia there is no generally accepted methodology for assessing the social and economic development of municipalities. In the decree of the President of the Russian Federation of April 28, 2008 No. 607 "On the assessment of the effectiveness of the activities of local self-government bodies in urban districts and municipal areas" a list of indicators is provided on the basis of which this assessment is carried out. However, this is only an assessment of the activities of local self-government bodies, and not an assessment of the level of socio-economic development of municipalities. All this determines the relevance of this issue and the need for a qualitative assessment of the differentiation of socio-economic development of municipalities.

\section{Theoretical base of the study}


The problems of territorial differentiation are constantly in the focus of attention of both domestic [6-11] and foreign scientists [12-20]. Their works offer different approaches to the analysis and assessment of intraregional differentiation and tools to overcome excessive inequality and its negative consequences.

\subsection{Purpose of the study}

The purpose of the study is to develop information and analytical tools based on the analysis of existing theoretical and methodological approaches and to assess the differentiation of the social and economic development of the municipal districts of the Voronezh region.

\subsection{General presentation of the study}

When studying the regional differentiation of the social and economic development of municipal districts, we propose to use a methodology based on an integral indicator, which is a characteristic of the social and economic development of municipalities, and is carried out from the standpoint of combining the social and economic level of development. When forming a system of indicators of the level of social and economic development of municipalities, the main requirements for their selection are taken into account: materiality (indicators should be useful in making adequate management decisions); compatibility (a set of indicators should fit into the existing system of information flows); reliability (the possibility of objective measurement of the values of indicators); differentiation (indicators should objectively reflect the differences between municipalities); completeness (the set of indicators should not miss the achieved level of development of various spheres of the municipality); simplicity (indicators should be understandable for a wide range of analysts); adequacy (a set of indicators should take into account the specifics of the activities of each municipality).

The indicators of the level of development of municipalities that meet the above requirements are combined into two groups: economic and social. The following indicators have been used for the assessment: economic (the volume of paid services, the commissioning of residential buildings, the total turnover of retail trade and public catering, the volume of investments in fixed assets, the average salary of employees of organizations); social (birth rate, mortality rate, crime rate, road density, hospital beds). Since the particular indicators of the social and economic development of municipalities have different dimensions and units of measurement, it is necessary to construct an integral indicator that assumes a transition to uniform characteristics. The following coefficients were calculated: the average coefficient of stability (Y_av), the average coefficient of the dynamics of development (D_av) and the final integral coefficient of social and economic development (I):

$$
I=\frac{Y_{\mathrm{cp}}+D_{\mathrm{cp}}}{2}
$$

On the basis of the calculations, 5 clusters were identified according to the level of differentiation of the social and economic development of municipalities: highly stable, above the regional average, average regional, below the regional average and depressed municipalities.

It is important to understand, when determining the group interval, that the value of the attribute of many socio-economic phenomena, and as a consequence of the final integral indicator, vary unevenly and on a large scale, therefore, in this study, we will use an 
unequal interval that progressively increases in arithmetic progression. Having estimated the range of variation of the final integral indicator, we assign the values $h_{i}=0.010$, and $\alpha$ $=0.005$, respectively.

The third stage consists in calculating and interpreting the result according to individual indicators of sustainability and dynamics of the social sphere, sustainability and dynamics of the economic sphere. Let us graphically represent it in the form of an integrated map (Fig. 1).

The group of districts with average regional values includes $(0.798-0.820) 15$ districts and territorially represents a ray formation with Bobrovsky district in the centre and districts diverging in different directions: to the north-west: Kashirsky, Novousmansky, Ramonsky, Semiluksky; to the east: Talovsky, Novokhopyorsky, Ternovsky, Gribanovsky districts and Borisoglebsky urban district; to the south, southeast: Buturlinovsky, Vorobievsky, Kalacheevsky, Petropavlovsky; to the south-west: Podgorensky district.

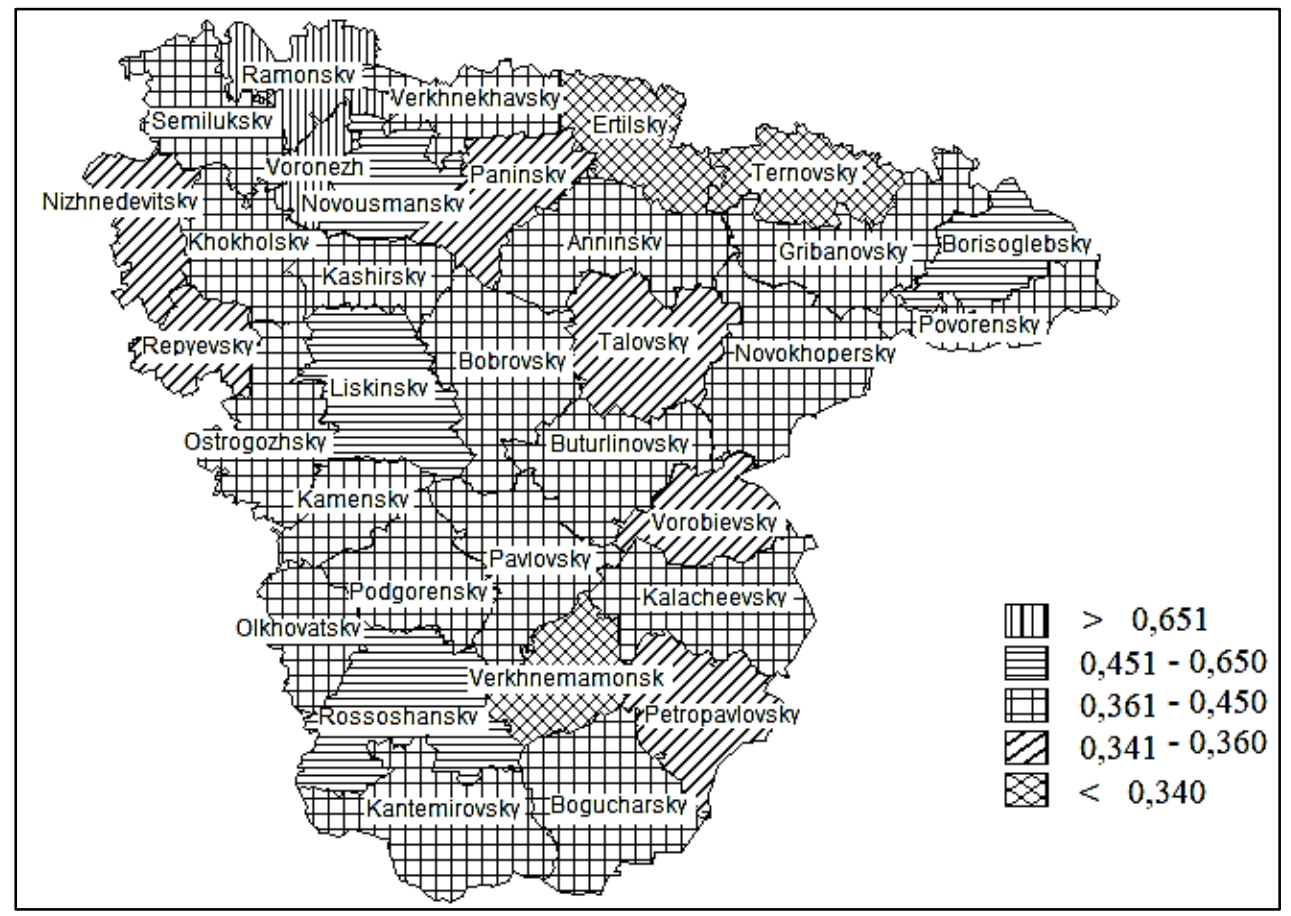

Fig. 1. Integral indicator of differentiation of social and economic development of municipal districts of the Voronezh region.

The areas with indicators below the average $(0.791-0.797)$ include: Verkhnekhavsky and Anninsky districts, located in the northwest; Pavlovsky and Olkhovatsky districts - in the south, southeast; Ostrogozhsky, Nizhnedevitsky, Khokholsky districts - in the west, northwest. The group of "depressed" $(<0.790)$ includes urban districts of Voronezh and Novovoronezh, as well as Liskinsky and Rossoshansky districts. The presence of these municipalities in this group is explained by the relatively low dynamics of the economic development indicator. Districts with indicators higher than the average regional are scattered around the region: in the west - Repyovsky and Kamensky; in the south Verkhnemamonsky and Kantemirovsky, in the east - Povorinsky. The leading regions in terms of the dynamics of socio-economic development are Bogucharsky in the south, 
Paninsky and Ertilsky - in the north of the region. In terms of the level of social and economic sustainability, the situation in the territorial context looks more homogeneous.

The eighteen districts of the region from the group with average regional indicators (0.361 - 0.450) are evenly distributed. The six districts are included in the group with indicators below the average regional $(0.341-0.360)$ : Nizhnedevitsky and Repyovsky - in the west, Paninsky - in the north, Talovsky - in the centre, Vorobievsky, Petropavlovsky in the south. All districts of this group are characterized by an unfavorable economic and geographical location, since they have a marginal position (except for the Paninsky and Talovsky districts), and far from the main transport roads and railways. Verkhnemamonsky, Ertilsky and Ternovsky districts are depressive $(<0.340)$. And if the Ertilsky and Ternovsky districts have an economic and geographical position that is unfavorable (the marginal position is far from transport highways), then the Federal Highway M 4 "Don" passes through Verkhnemamonsky district, so the territory of this district has a great logistical potential. Also, Verkhnemamonsky district borders with the territories of advanced development Rossoshansky, Pavlovsky and Kalacheyevsky districts, which should contribute to its development through economic ties with these territories. Novousmansky, Liskinsky, Rossoshansky districts and Borisoglebsky city district form a group with indicators higher than the regional average (0.451-0.650). These areas have a favorable economic and geographical location and demonstrate high economic and social indicators.

\section{Conclusion}

So, the proposed method, having individual features in limiting the number of basic indicators, allows us to identify territories with a relatively low level of development, as well as to identify problematic parameters of socio-economic development within the municipalities themselves. All this makes it easier to choose an effective strategy for the development of these territories, both through budget planning and through the development of a competent investment policy. An analysis of the features of the balanced development of municipalities is necessary for both local self-government and regional authorities, and one of the main directions of their activities should be to reduce the backlog of economically less developed municipalities.

The study was carried out with the support of the RFBR grant 19-35-90021.

\section{References}

1. N.V. Yakovenko, Socio-economic stability of the depressed region (Ivanovo region), Bulletin of Tambov University. Series: Natural and Technical Sciences, 18(2), 731-736 (2013)

2. N.V. Yakovenko, Depressive regions of Russia: methodology, theory, practice (Ivanovo: State Unitary Enterprise "Ivanovo Publishing House", 2013)

3. N.V. Yakovenko, Yu.V. Porosenkov, Theoretical approaches to the study of the depressive regions of Russia, Bulletin of Voronezh State University. Series: Geography. Geoecology 2, 10-21 (2013)

4. N.V. Yakovenko, I.V. Komov, O.V. Didenko, Strategic planning as a tool for managing territorial development: theoretical aspects / monography: Management of socio-economic systems: theory, methodology, practice (Penza: MCSC "Science and Enlightenment", 2017) 
5. N.V. Yakovenko, I.V. Komov, R.V. Ten, Cluster Approach in Assessing the Level of Socio-Economic Development of the Municipal Districts (Voronezh Region), Advances in Economics, Business and Management Research 79, 201-203 (2019)

6. E.M. Buchwald, O.B. Ivanov, Actual problems of spatial integration of the Russian economy, STAGE: Economic theory, Analysis, Practice 5, 7-13 (2015)

7. A.G. Granberg, Fundamentals of regional economics (M.: HSE, 2000)

8. O.V. Gritsai, G.V. Ioffe, A.I. Treyvish, Center and periphery in regional development. (M.: Science, 1991)

9. O.V. Kuznetsova, Pyramid of factors of socio-economic development of regions, Problems of Economics 2, 121-131 (2013)

10. I.D. Turgel, Local asymmetry of regional development: content, assessment, socioeconomic consequences.

URL: http://ecsocman.edu.ru/data/771/668/1219/012_Turgel_I.pdf.

11. A.R. Bakhtizin, E.M. Bukhvald, A.V. Kolchugina, Alignment of Russia's regions: program illusions and economic realities, Bulletin of the Institute of Economics of the Russian Academy of Sciences 1, 76-91 (2016)

12. C. Hadjimichalis, Non-Economic Factors in Economic Geography and in 'New Regionalism': A Sympathetic Critique, International Journal of Urban and Regional Research 30, 3, 690-704 (2006) doi: 10.1111/j.1468-2427.2006.00683.x.

13. A. Kauffmann, Das Städtesystem der Russischen Föderation aus Sicht der Neuen Ökonomischen Geographie. Potsdam: Univer-sitätsverlag Potsdam, occurrence, identification and elimination (Ostrava: VŠB-Technical University of Ostrava, 2010)

14. T. Lang, Socio-economic and political responses to regional polarisation and sociospatial peripheralisation in Central and Eastern Europe: a research agenda, Hungarian Geographical Bulletin 64, 3, 171-185 (2015) doi: 10.15201/hungeobull.64.3.2.

15. F. Naschold, J. Bogumil, Modernisierung des Staates: new public management in deutscher und internationaler Perspektive (Wiesbaden: Springer Fachmedien GmbH. 2000)

16. M.E. Porter, Regions and the New Economics of Competition: Global City-Regions: Trends, Theory, Policy (Oxford: Oxford University Press, 2001)

17. M. Porter, 2006 Competition (M.: Williams Publishing House, 2006)

18. J. Pickles, A. Smith, Theorising Transition. The Political Economy of Post-Communist Transformations. Taylor and Franci.s (1998)

19. P.R. Krugman, Geography and Trade (Cambridge: MIT Press, 1991)

20. Ph. Martin, The Geography of Inequalities in Europe, Swedish Economic Policy Review 12, 83-108 (2005) 